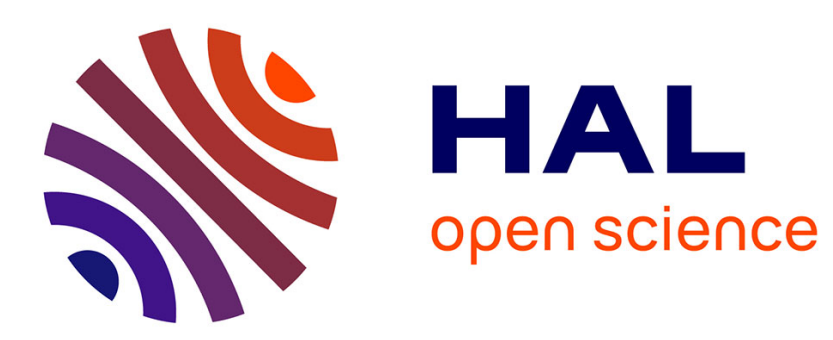

\title{
Measuring the contribution of extractive industries to local development : the case of oil companies in Nigeria
}

Diongue Abdou Ka, Gaël Giraud, Cécile Renouard

\section{To cite this version:}

Diongue Abdou Ka, Gaël Giraud, Cécile Renouard. Measuring the contribution of extractive industries to local development: the case of oil companies in Nigeria. 2011, pp.30. hal-00626247

\section{HAL Id: hal-00626247 \\ https://essec.hal.science/hal-00626247}

Submitted on 24 Sep 2011

HAL is a multi-disciplinary open access archive for the deposit and dissemination of scientific research documents, whether they are published or not. The documents may come from teaching and research institutions in France or abroad, or from public or private research centers.
L'archive ouverte pluridisciplinaire $\mathbf{H A L}$, est destinée au dépôt et à la diffusion de documents scientifiques de niveau recherche, publiés ou non, émanant des établissements d'enseignement et de recherche français ou étrangers, des laboratoires publics ou privés. 


\title{
Measuring the contribution of extractive industries to local development : the case of oil companies in Nigeria
}

\author{
Research Center \\ ESSEC Working Paper 1109 \\ July 2011
}

Abdou Kâ Diongue

Gaël Giraud

Cécile Renouard 


\title{
Measuring the contribution of extractive industries to local development : the case of oil companies in Nigeria
}

\author{
Abdou KÂ Diongue* \\ Saint Louis University, Senegal \\ GAËL GIRAUD ${ }^{\dagger}$ \\ CNRS, Paris School of Economics, ESCP-Europe.
}

CÉcile RenouarD ${ }^{\ddagger}$

Essec Business School, France.

July 30, 2011

\begin{abstract}
Extractive industries face two main challenges in terms of CSR and poverty reduction: 1) recognize that societal activity is part of their core business; 2) take part in socio-economic projects that contribute to their stakeholders' empowerment and not only to their living conditions. Based on surveys achieved in Nigeria in 2008, the paper presents two societal performance indices meant to be complementary: the Poverty Exit Index (PEI) and the Relational Capability Index $(\mathrm{RCl})$. We show that, while they have fostered the $\mathrm{PEI}$ of the local communities, the development projects of the oil companies had a rather negative impact on their $\mathrm{RCl}$. We then identify key variables that can influence positively the $\mathrm{RCl}$ and on which a sensible development policy should focus.
\end{abstract}

Keywords: development indices, capability approach, relational capability, development, poverty, impact assessment.

JEL Classification Numbers : C43, D21, F21, L71, O12, O55.

\footnotetext{
*abdou.diongue@ugb.edu.sn

${ }^{\dagger}$ gael.giraud@parisschoolofeconomics.fr

${ }^{\ddagger}$ renouard@essec.fr
} 


\section{Introduction}

In order to assess the impact of development programs led by public or private actors, several measurement tools have been proposed in the past years, as alternatives to income. This paper builds on the work initiated by Amartya Sen and expanded by the UNDP (Human Development Report), the Human Development and Capability Association and the Oxford Poverty and Development Initiative (OPHI) led by Sabina Alkire. In 2010 the OPHI and UNDP have introduced a Multidimensional Poverty Index which entails 3 components: health, education, and living standards. The justification for the choice of these components is threefold: key importance of these areas in terms of human development and Millenium Development Goals; consensus reached on the importance of these components from a practical perspective (thanks to a participative methodology) and from a theoretical one (universal recognition of health, education and living conditions as core dimensions of human rights); data constraints. The initiators of this index underline the importance of focusing on other human capabilities too. Sabina Alkire stresses that "a key priority for future work on multidimensional poverty must be gathering more and better data around core areas such as informal work, empowerment, safety from violence, and human relationship (social capital and respect versus humiliation). This will enable empirical exploration of whether such dimensions add value to a multidimensional poverty measure." This paper explores some of these dimensions, by defining two new indices: a Poverty Exit Index which is close to the Multidimensional Poverty Index and a Relational Capability Index which focuses on the quality of relationships among people and on their level of empowerment. We then apply these indices to the measurement of the impact of oil companies on local communities in the Niger Delta (Nigeria).

\section{CSR and development}

What should be the responsibility of extractive industries in tackling poverty and in developing their areas of influence? In the past, many companies were somewhat reluctant to manage development policies because they did not want to be considered either as government's substitutes or as development agencies. Generally, their societal activity was limited to charitable donations to communities or NGOs. Later on, as they faced violent claims from diverse groups (civil society, local communities, etc.), some of them have begun to implement projects aimed at providing basic goods and services to local people in order to foster development. Still, these projects are usually conceived in a defensive way. Companies implement new programs and claim that they consider as strategic tool to bring 
peace and stability. However, the content and scope of their activities are not well defined. In this paper, we distinguish between diverse companies' contributions to development: through the taxes and royalties they pay to the government ; through their social policies (wages, social welfare, etc.); through local content; and through socio-economic actions for the local communities. Those actions are either voluntary or mandatory (required by the government). In the past, multinationals have implemented different kinds of social and environmental norms in developed and developing countries. They may have neglected the environmental issues in developing countries. As far as local communities are concerned, philanthropic and paternalistic behaviors have often replaced any effort to take part in coordinated development programs. Nowadays, some of them recognize the necessity for a paradigm shift in order to promote sustainable development in the areas where they are operating. (Blowfield \& Frynas, 2005).

We defend the idea that societal responsibility has to be clearly defined, as something radically different from philanthropy. Recently, a few groups have discussed the content of societal curricula and the related careers within them: they need to favor a development of engineers' know-how that takes into account the variety of stakeholders and new skills, in order to be able to meet the demand for a more sustainable contribution of private actors to local development. Some criteria of societal performance are being published by different kinds of organizations (GRI, IFC, Iso 26000, etc.)

Our paper provides two indices aimed at assessing and following the societal performance of companies. We use both quantitative and qualitative field surveys which have been led in the Niger Delta, in Nigeria, between 2004 and 2010. The areas where the surveys have taken place are impacted by the onshore and/or offshore oil production. We analyse the Nigerian context and the financial contributions of oil companies to government and local communities. We show that addressing sustainable development issues comes to deal with: a) the assessment, the minimization and the mitigation of the direct and collateral damages related to oil production ; b) the contribution to projects improving the quality of social networks and the empowerment of the stakeholders and not only the living conditions of the populations impacted by oil production. Finally, we present the new models set up by Total in two areas and we define two indices of societal performance. 


\section{New Model needed for oil companies and devel- opment}

Nigeria's population amounts to 149 million inhabitants, and its average age is 18 years (CIA 2010). It is ranked 159th out of 177 according to the 2006 HDI, with a life expectancy of 47 years. In $2007,70 \%$ of the population was living under the poverty line. Oil production began in Nigeria in 1953, a long time after an oil mining license had been granted to Shell/BP in 1938. Other oil mining licenses were obtained by Mobil, Safrap, Philips and Agip in the 1950's. The federal government has seen its influence increased since the end of the 1960's, and particularly since 1971 when Nigeria became a member of the OPEC, the world organization of oil producers. The impact of the oil industry on economic growth became obvious in the 1970s, when Nigeria became one of the world leaders in oil production and exportation. This was partly due to the increase in oil revenues following the rise in black gold prices. Oil prices in current dollars were multiplied by 4 between 1970 and 1973, by 15 between 1970 and 1981, and by 25 between 1970 and 2005: i.e., $\$ 2.43$ in 1970, $\$ 40$ in 1991, $\$ 62$ in 2005, $\$ 70$ in 2006 (Bach 1999, Moreau-Defarges 2006).

Since 1960 several national development plans have been implemented, but they did not bring any substantial change in the living conditions of the population. General Abacha's military dictatorship during the 1990s led to increased corruption and internal conflicts. Since President Obasanjo's election in 1999, and its re-election in 2003, fighting corruption and fraud have become priorities and are combined with the growth promotion of the industrial sector (outside of the oil and gas industry). Realizing that several huge public industrial projects ${ }^{1}$ have generated low productivity, the government decided to privatize some sectors. It raised the external tariffs in order to protect industries with lower competitiveness and increase production of locally manufactured goods. The new President Yar'Adua, who was elected in spring 2007 - deceased in spring 2010-, decided that the two major goals of his presidency would be the reduction of corruption and the promotion of Niger Delta regional development.

In this context, the political and ethical challenges faced by oil producing firms such as Total and Agip can be clearly addressed. On the one hand, in order to be accepted, multinationals give money to traditional chiefs and local leaders, but this money is rarely spent for the benefit of the whole community. On the other hand, the people, members of these communities,

\footnotetext{
${ }^{1}$ The average used rate of industrial equipment amounted to $32.7 \%$ in $1999,51.3 \%$ in 2002 .
} 
who can not easily express their resentment against these political leaders, thus target the foreign oil companies to express their feelings of injustice through threats, sabotage, kidnappings of expatriates and nationals and other violent actions.

The communities of the oil producing states also express their discontent, which results from a change in the distribution of oil revenues by the federal government. This distribution is now related to population growth, therefore diminishing the share granted to oil producing areas, where population grows less. The share of oil producing areas has progressively decreased from $45 \%$ in 1971 to $20 \%$ in 1979 and $13 \%$ today. Within this context, violence in the Niger Delta grew up with the deterioration of the socio-economic situation and the disappointment of emancipation movements' leaders (such as the Ijaws), who demand access to the political power.

In the meantime, the recognition of key ethical principles by oil multinational companies, as defined by international agreements - such as the EITI (extractive industry transparency initiative), launched in 2002- and their own Codes of Conduct, expresses a moral commitment toward local communities. Multinationals increasingly become morally and legally accountable as civil society places greater pressure on them.

This new way of thinking clearly contrasts with the past years of inconsistent development aid towards local communities. Its objective is to generate a fairer order based on an effective sustainable local development. In our opinion, CSR entails two main dimensions: the first consists in holding corporations accountable for minimizing and repairing their negative sideeffects on the natural and human environment (Bomann-Larsen \& Wiggins, 2004; Renouard, 2007). Oil companies have often failed in addressing these issues (for instance, regarding the impact of gas flaring on the health and on the living conditions of local people and the effects of pollution on fishing and farming - sources of livelihood, in the Niger Delta - Idemudia, 2009a). This first responsibility can be defined as the "do no harm" principle. The second kind of social responsibility of multinationals relates to its positive contribution to local development, in terms of "local content" (hiring local employees and contracting with local contractors), educational training, and socio-economic development. This requires some kind of cooperation between multinationals and other stakeholders in order to address all political and institutional issues efficiently, knowing that oil companies are not development agencies. Such a challenge implies implementing adequate programs run by relevant entities that would acknowledge the positive role of communities, local governments and companies (Renouard, 2008). Such a solution is more efficient than a direct contribution of companies to commu- 
nities.

Multinational corporations operating in the developing world are illequipped to tackle development issues (Frynas, 2008, Blowfield \& Frynas, 2005), because of past confusion between philanthropy and real contribution to local development, and because of their lack of internalization of negative externalities within their core business activities. Moreover, they also have to deal with local governance problems and weak or failed states. Traditional structures have difficulties promoting projects that comply with the international standards related to local sustainable development. For instance, in Nigeria, women usually do not take part in the decision-making process and do not participate in the communities' regulating bodies. Youth groups, empowered by the constitution of local government areas in 1976, have also emphasized the leaders' corruption during the discussions about the setting up of a Memorandum of Understanding (MoU) between oil companies and local communities in order to be formally recognized as legitimate partners. However, these groups may also be manipulated by local elites and only pursue their own private interests (Watts 2003, Pratten 2006 p.712). Civil servants are often corrupt and absent: for instance, although the NDDC receives $3 \%$ of the investment budget of oil companies (e.g. 30 million dollars from Total every year), very few projects have been carried out on the ground.

The Nigerian political network includes various heterogeneous and unstable institutions where strategies and tactics are developed by different kinds of public representatives and groups from the civil society. Oil companies are part of the system and play an active role in these power games without measuring systematically the implications (Frynas, 2005). Within this context, local development entails the combination of different categories of actors. It is not only the companies' duty to deal with the community representatives - -which are often self-proclaimed as such. To deal with the risk of manipulation, embezzlement, and project politicization, a third party is needed to foster the voices of the various social types of people. Therefore, the implementation of new structures, like the NGO Pro Natura in the Niger Delta communities impacted by the oil offshore production, seems to be a solution to make multinationals behave in a fairer and more objective way with local communities, so that a sustainable social peace can be achieved.

\section{Total's contribution to local development}

Total (TEPNL) Company is the 8th larger oil exporter in the world and owns a huge oil-proved stock, i.e., 37.5 billion barrels according to 2007 estimates. 
Total's oil production represents $10 \%$ of Nigeria's global production and exportations reached 2.5 millions of barrels per day in 2004 .

Half of the revenue generated by Total's production activity went to national companies. In 2004, the taxes paid represented 10 times the salaries paid by the company and 100 times its societal commitment. In 2008, Total's societal expenses amounted 120 million euros for non-OECD countries, half of it resulting from contracts with country states like in Nigeria, Gabon, or Congo... More generally, around one per thousand of the turnover is related to societal involvement.

Production (oil and gaz) of Total in Nigeria

\begin{tabular}{|c|c|c|c|}
\hline \multicolumn{4}{|c|}{ Production SEC (Security and Exchange Commission) of Total in Nigeria } \\
\hline & Combined Production $(\mathrm{k} \mathrm{b} / \mathrm{d})$ & Oil $(\mathrm{k} \mathrm{b} / \mathrm{d})$ & $\operatorname{Gaz}(\mathrm{Mpc} / \mathrm{d})$ \\
\hline 2000 & 163 & 137 & 133 \\
\hline 2008 & 246 & 158 & 436 \\
\hline 2009 & 235 & 159 & 374 \\
\hline
\end{tabular}

Total payments to the federal Nigerian government and to NDDC in 2008 (Source: Total for EITI) ${ }^{2}$

\begin{tabular}{|l|c|c|}
\hline Millions of US dollars & $\mathbf{2 0 0 8}$ & $\mathbf{2 0 0 9}$ \\
\hline PPT (Petroleum Profit Tax) & $1,982.9$ & 509.3 \\
\hline Licence fee - oil & 968.5 & 460.4 \\
\hline Licence fee - gaz & 13.9 & 19.0 \\
\hline Other taxes & 154.6 & 198.0 \\
\hline Total & $\mathbf{3 , 1 1 9 . 9}$ & $\mathbf{1 , 1 8 6 . 7}$ \\
\hline
\end{tabular}

Moreover, the Federal government also received 1,580 millions Nairas in 2008, and 9,703 millions Nairas in 2009 as Total's contribution to the Niger Delta Development Commission (NDDC).

In Nigeria, Total runs two types of sites: (i) an onshore production site in Obagi/Onelga (in the Rivers state), where the company has been producing oil and gas for fifty years; and (ii) a new zone of offshore production which impacts on the coastal communities (e.g. Eastern Obolo LGA). To assist the communities near Obagi, Total supports various programs on infrastructures, scholarships, training programs, micro-credit, etc. In the coastal areas, which suffer from pollution and social instability due to the conflicts about oil revenues distribution, the company committed itself, since 2002, by supporting the activities of an NGO: Pro Natura. Pro Natura had already implemented a participatory development program in Akassa, a coastal area of Bayelsa state, which is impacted by BP and Statoil.

\footnotetext{
${ }^{2}$ All the taxes paid by Total in Non-OECD countries amount to 14.8 G Euros in 2008.
} 
When comparing the two areas where Total is operating, one may make a distinction between a 'paternalistic scheme', like the one implemented in Obagi for years and a new 'participatory scheme' like in Eastern Obolo.

In the area of Obagi, Total has been directly operating for more than fifty years and people enjoy much higher living conditions than in Eastern Obolo, where Total only operates indirectly and with a far lesser extent through a local foundation initiated by the Pro Natura, i.e. EOCDF (Eastern Obolo Community Development Foundation). However, Obagi's dependency on Total feeds into corruption networks and generates rivalries and frustrations which appear to be counterproductive in the long term.

In the area of Eastern Obolo, empowerment appears to be much stronger (Idemudia, 2009a). Two examples confirm this situation. First, when Pro Natura left Eastern Obolo in the summer 2008, the local foundation EOCDF relied on its own human resources and management abilities to deal with the funds provided by several donors, including Total. The second instance refers to the implementation of microcredit schemes. Between 2004 and 2006, Total directly financed in Obagi an amount of 57.8 million Naira (330,000 euros) helping groups of 10 to 15 members. In Eastern Obolo, EOCDF managed only a 1.5 million Naira (9,000 euros) project. However, the number of beneficiary groups was 58 in Obagi and 30 in Eastern Obolo. The repayment rate was extremely low in Obagi (4 groups out of 31 in 2005, and 5 groups out of 27 in 2007) while in Eastern Obolo the repayment rate reached $100 \%$ and was made in the required time.

Therefore, as far as means are concerned, a partial externalization of Total's societal responsibilities seems to foster the empowerment of the people and lead to a sustainable development of the communities.

Here are some general characteristics of the sample we have scrutinized.

Level study

\begin{tabular}{|ccc|cc|}
\hline & \multicolumn{2}{c}{ Eastern Obolo } & \multicolumn{2}{c|}{ Onelga } \\
& Number & $\%$ & Number & $\%$ \\
\hline Not attended & 72 & 10.37 & 48 & 7.95 \\
Primary & 264 & 38.04 & 133 & 22.02 \\
Secondary & 278 & 40.06 & 297 & 49.27 \\
Post-secondary & 70 & 11.53 & 111 & 20.86 \\
\hline
\end{tabular}


Status of employment activity

\begin{tabular}{|cccccc|}
\hline & $\begin{array}{c}\text { Eastern Obolo } \\
\text { Number }\end{array}$ & $\%$ & Onelga \\
& 5 & .87 & 90 & 17.14 \\
Daily/weekly wage worker & 142 & 24.78 & 69 & 13.14 \\
Contract worker & 7 & 1.22 & 21 & 4 \\
Occasional worker & 13 & 2.27 & 29 & 5.52 \\
Apprentice & 9 & 1.57 & 8 & 1.52 \\
Family helper & 14 & 2.44 & 18 & 3.43 \\
self-employed & 300 & 52.36 & 258 & 49.14 \\
Employer & 37 & 6.46 & 12 & 2.29 \\
Other & 46 & 8.03 & 20 & 3.81 \\
\hline
\end{tabular}

Demographic structure

\begin{tabular}{|ccc|}
\hline & Eastern Obolo & Onelga \\
Average age & 36.99 & 39.13 \\
Median age & 35 & 37.5 \\
Std. dev. age & 12.17 & 13.84 \\
Skewness age & .72 & .74 \\
Kurtosis age & 3.11 & 3.07 \\
Min. age & 18 & 15 \\
Max. age & 76 & 84 \\
1st quartile age & 28 & 28 \\
3rd quartile age & 45 & 48 \\
\hline
\end{tabular}

\begin{tabular}{|cccccc|}
\hline & \multicolumn{2}{c}{ Eastern Obolo } & \multicolumn{2}{c|}{ Onelga } \\
Gender & Number & $\%$ & Number & $\%$ \\
\hline Male & 401 & 54.78 & 321 & 53.15 \\
Female & 331 & 45.22 & 283 & 46.85 \\
& & & & \\
Age profile & & & & \\
\hline $15-35$ & 328 & 44.81 & 252 & 41.72 \\
$35-65$ & 380 & 51.91 & 316 & 52.32 \\
$>65$ & 24 & 3.28 & 36 & 5.96 \\
& & & & \\
Marital status profile & & & & \\
\hline Single & 163 & 22.27 & 106 & 17.55 \\
Married & 486 & 66.39 & 476 & 78,81 \\
Widow & 68 & 9.29 & 13 & 2.15 \\
Separated & 15 & 2.05 & 9 & 1.49 \\
\hline
\end{tabular}

Loans 


\begin{tabular}{|c|cc|cc|}
\hline \multicolumn{2}{|c}{ Eastern Obolo } & \multicolumn{3}{c|}{ Onelga } \\
From whom did you & Number & $\%$ & Number & $\%$ \\
\hline borrow money & & & & \\
\hline Husband/Wife & 2 & 2,56 & 1 & 0,77 \\
Father/Mother & 0 & 0,00 & 4 & 3,08 \\
Brother/Sister & 4 & 5,13 & 5 & 3,85 \\
Other relative & 7 & 8,97 & 24 & 18,46 \\
Friend & 9 & 11,54 & 25 & 19,23 \\
Local/religious leader & 9 & 11,54 & 11 & 8,46 \\
Bank/saving and loans & 2 & 2,56 & 8 & 6,15 \\
Boss/employer & 1 & 1,28 & 0 & 0,00 \\
Professional money lender & 6 & 7,69 & 7 & 5,38 \\
NGOs & 5 & 6,41 & 29 & 22,31 \\
Companies (EPNL/AGIP) & 6 & 7,69 & 0 & 0,00 \\
Others & 27 & 34,62 & 16 & 12,31 \\
\hline
\end{tabular}

Obviously, only a few people did borrow money in the recent past. We shall see later on that access to credit plays a major role in people's empowerment.

\section{The measure of Total societal performance in Nigeria}

\section{1 indices}

Let's now describe the guidelines which could be used to compare the empowerment of individuals and the living standard. Of course, our goal is not to minimize the importance of programs that fight against material poverty. That is why we have developed an index of escaping poverty, based on the model proposed by Mohammed Yunus of Bangladesh. The index is used by the Grameen Bank to evaluate how micro-credit programs allow beneficiaries to escape poverty. This index provides an insight on the levels of economic underdevelopment in the concerned areas. It does not provide, however, any information, by itself, about the cooperation between individuals, their ability to make choices and to get involved in their political community nor, in general, the corporate culture. That is why the relational capability index (Giraud \& Renouard, 2009) complements this first escaping poverty index. The idea is to direct the actions led by government institutions as well as by the international institutions and private actors (companies, NGOs, etc.) 


\subsubsection{Poverty Exit index (PEI)}

Several types of indices are used to measure the standard of living of populations. The HDI (Human Development index) developed by the UNDP incorporates the linked with the GDP per inhabitant, the life expectancy at birth, the rates of primary education and adult literacy. Thus, it measures at the same time the average level of wealth, access to health and access to education of a population.

Our Poverty Exit Index is closer to the Multidimensional Poverty Index (MPI), launched by the Oxford Poverty and Human development initiative and the Human Development Report Office in July 2010 (Alkire and Santos (2010)). This MPI Index entails 3 dimensions (education, health and living standard) and 10 indices: Nutrition, Child mortality, years of schooling, children enrolled, cooking fuel, toilet, water, electricity, floor, and assets. Our Index entails the same 3 dimensions. There are three differences, however:

1. We focus on the poverty exit level of people and not on the poverty level. As a consequence, the poorer people are, the lower is our index, the higher is the MPI.

2. The assets considered are:

\section{Assets}

Radio, tape recorder
Television
Computer
Oven, hotplate
Refrigerator
Mobile phone
Bicycle
Motorbike
Car
Tractor
Generator
Kerosene lamp
Sewing machine
House or apartment

The variable "assets" is computed as an average of the answers (yes $=1$, no $=0$ ) for each belonging.

3. In this survey, we measure the situation of individuals (adults) and not of the whole household. This explains why we focus on the number of years of schooling. The "children enrolled" indicator is therefore absent 
from our index.

Our Poverty Exit Index is also linked with the criteria introduced by M. Yunus, which aim at assessing whether a person has escaped poverty. Yunus emphasizes himself that this list should be adapted according to the local context. The following criteria are given by Yunus (2008) in order to appreciate the efficiency of programs fighting against poverty:

Yunus' criteria

A tin-roofed house (or a value equivalent to $\$ 370$ )

Access to drinkable water

Clean toilets

Grammar school education

Three complete meals per day

Sufficient clothes and protections (mosquito nets)

Possibility of having medical expenses taken care of in case of illness

Savings account with at least $\$ 75$

Sources of additional income possible in case of difficulty

Thus, the criteria proposed by Yunus take up the three dimensions considered by the HDI (income, health, education) but elaborate them in terms of material life conditions, simply adding elements concerning the ability of people to save. It is worth noticing that almost all the variables under scrutiny concern functionings of individuals. Two criteria are linked to the capabilities of people, regarding the means to face unforeseen difficulties or disease. Finally, the index doesn't address the social and political context the populations are living in, nor their ability to make decisions, nor their civil and political rights.

\subsubsection{Relational Capability index (RCI)}

The relational anthropology we favour states that personal identity is shaped in the relationship with otherness. We therefore define the implementation of the relational capability as a key condition of human development. We distinguish four components of this capability at the individual level (Renouard, 2010): 
Relational Capability Index (RCI)

\begin{tabular}{|c|c|c|c|c|}
\hline \multirow[t]{2}{*}{ Components } & \multicolumn{2}{|l|}{ Indicators } & \multicolumn{2}{|l|}{ Weights } \\
\hline & & $\begin{array}{c}\mathrm{RCI}_{0} \\
\text { Uniform }\end{array}$ & $\begin{array}{c}\mathrm{RCI}_{1} \\
\text { Dynamic }\end{array}$ & $\begin{array}{c}\mathrm{RCI}_{2} \\
\text { Dynamic (SA) }\end{array}$ \\
\hline $\begin{array}{l}\text { Living conditions- } \\
\text { Integration } \\
\text { to networks }\end{array}$ & $\begin{array}{l}\text { Level of education } \\
\text { Access to information } \\
\text { Income/assets } \\
\text { Employment status }\end{array}$ & $25 \%$ & $1-\mathrm{PEI}_{1}$ & $1-\mathrm{PEI}_{2}$ \\
\hline Political commitments & $\begin{array}{c}\text { Vote } \\
\text { Participation to groups } \\
\text { Cooperation among groups }\end{array}$ & $25 \%$ & $\frac{\mathrm{PEI}_{1}}{3}$ & $\frac{\mathrm{PEI}_{2}}{3}$ \\
\hline Private relations & $\begin{array}{c}\mathrm{Nb} \text { of friends } \\
\mathrm{Nb} \text { of financial supports } \\
\mathrm{Nb} \text { of people loved by }\end{array}$ & $25 \%$ & $\frac{\mathrm{PEI}_{1}}{3}$ & $\frac{\mathrm{PEI}_{2}}{3}$ \\
\hline Solidarity & $\begin{array}{c}\text { Common interest activities } \\
\text { Confidence in others } \\
\text { Unity in the village }\end{array}$ & $25 \%$ & $\frac{\mathrm{PEI}_{1}}{3}$ & $\frac{\mathrm{PEI}_{2}}{3}$ \\
\hline
\end{tabular}

1) The living conditions (in terms of integration into networks) constitute the first component of the RCI. Network is defined very broadly as a set - open or closed - of relationships - horizontal and vertical — organized in a society. From the first network where the newborn is integrated, his/her family, to the community that surrounds the deceased person, human life is spent in networks. At this stage, we consider imposed and inherited networks as well as chosen networks. Part of our identity takes shape in relation to given networks and part of it as a result of our voluntary commitment to others. Lack of freedom - the definition of prison - is a means to prevent people from belonging to networks, hence to social life. Exclusion is characterized by the absence of participation in networks due to isolation and inability to evade it (Boltanski \& Chiapello, 1999). The lack of exercise of relational capability can be measured through this index of a weak participation in networks - whether institutional or not.

2) The second component is related to political commitment, this voluntary association with others for a specific project with a common good or a collective interest. It implies being part in the decision making process within a political community. We focus here on the chosen networks and more specifically on the personal commitment in society. Such a commitment can take different forms: political, social, etc. Stressing the importance of such commitments is closely related to the definition of a "fair society" as 
a society that promotes a complex equality (Walzer, 1983) among citizens: it implies the assessment of anybody's capability in a given community to be recognized in one or another sphere of his life, and this recognition is facilitated by the active and autonomous involvement in a social network. This perspective implies that the measures taken to avoid the pre-emption of a few people over certain functions and their domination on different domains of social life: for example when the richest are also leading the political game, control the access to the best education for their children, etc. This commitment to different networks in a pluralist society can be measured by several indices: political vote, participation of the worst off in the decision making process at a local level, voluntary commitment to a group or association within the community, nature and objective of the selected project.

3) The third component of the relational capability regards social inclusion, the feelings in interpersonal relationships, friendship and love. Human growth is favoured by the quality of love a human being receives and gives. This love may be more or less exclusive, and implies the relation between free persons in the aforementioned meaning. Love is the highest expression of the human freedom as autonomy and interdependence. Thus we can measure it through different indices: by whom a person feels he/she is loved, the number of close friends, the number and nature of the persons whom he/she could rely on in case of emergency (financial, professional problems, etc.)

4) The fourth component of the relational capability consists in solidarity, in the sense that the others' goals are valued by considering them as ends in themselves. This attitude consists in extending the special care for somebody - through friendship and love - to any interpersonal relation, either direct or mediatized by institutions. This is exactly what Paul Ricœur calls the "logic of overabundance", concerning the implementation of the biblical Golden Rule in social networks (Ricœur, 1990). The negative definition of the Golden Rule ("Do not do to others what you do not want them to do to you") is close to a minimal and negative ethical principle ("do no harm") and expresses a logic of equivalence. But the Golden Rule in its positive definition ("do unto others as you would have them do unto you") has a broader meaning: it is an invitation to contribute actively to the other's good, without expecting any reciprocity. It opens the door to an excess: give without expecting an equivalent gift in return. This attitude involves face to face encounters but it may be integrated in social, economic and political institutions: it enables the respect of the uniqueness of every per- 
son and expresses the objective of a social organization serving the dignity of each of its members. We can measure this component by the time and energy freely given to community projects, by the level of trust in a given community. This component may also be used to assess the quality of the relation between groups within a society and between societies.

\subsection{Data collection issues}

Specific surveys were designed to collect the data that will help address the previous issues. We will focus on the survey led in 2008 in two areas impacted by oil production.

\subsubsection{The sample design}

Two types of samples were selected within the two sites of Obagi/Onelga, in the Rivers state, and Eastern Obolo in the Akwa Ibom state. Their respective populations were estimated at 60,540 in Eastern Obolo and 284,010 at Obagi. ${ }^{3}$ Samples on individuals, amounting to 610 in Obagi and 732 in Eastern Obolo, were selected on a random basis, while samples on leaders, amounting respectively to 264 and 310, were chosen on a purposive basis.

The selection of individuals was carried out through several steps. First, on the two sites, communities were selected according to specific criteria, i.e. their location, their size, the type of development infrastructures. 28 communities were chosen in Eastern Obolo and 22 in Onelga. In Onelga, four different types of communities were chosen: Total core communities and Agip core communities are communities where several landlords have sold their land. Thus the companies have signed MoUs with these communities. There are also Total non core communities and Agip non core communities, which are communities close to the core ones but with non landlords. In addition to the specific MoU with the Oil \& Gaz families (core communities),Total has signed a global agreement with the Egi clan, which encompasses both core and non core communities; on the contrary, Agip hasn't signed any global MoU with the two clans where it operates. Thus it is interesting to compare the situation in both core and non core communities. Second, within each community, about 24 to 30 individuals and 10 to 12 leaders were interviewed. Leaders were selected according to their function within the community (e.g: paramount ruler, elder, CDC chairman, youth group leader, women group leader, religious leader). Individuals were selected by following a random path: the six surveyors walked from the house

\footnotetext{
${ }^{3}$ Federal Republic of Nigeria, Official Gazette, vol. 94 (24), May, 15 ${ }^{\text {th }}, 2007$.
} 
of the village head, each one going in a different direction, and selecting a household each 100 feet. One individual was then chosen in the household respecting gender and age (16 to 80) quota.

Doing so, a total of 1906 questionnaires, respectively 1032 in Eastern Obolo and 874 in Onelga, were filled in during the four months of field operations: in January and February 2008 for Eastern Obolo, and in April and May for Obagi/Onelga.

\subsubsection{The content of the questionnaire}

The questionnaire focusing on individuals entails two parts. The first one aimed at providing the characteristics of the interviewee and his/her income sources. The second part addresses the daily quality of life for each person, including the perception of his/her functionings and capabilities, and focusing on all aspects related to the relational capability. The information collected through the questionnaire will allow measuring the poverty level as well as the relational capability and its link with people's empowerment.

As far as poverty is concerned we have adapted the criteria given by $\mathrm{M}$. Yunus to the Nigerian context (by asking local people about their criteria of utter poverty). We measure the poverty threshold (Poverty Exit index) using the following 8 criteria:

\section{Poverty Exit index}

Regular access to drinking water
Electricity
Easy access to the house by road or boat
A house with walls not made of mud/thatch
Three meals per day
Easy access to medical treatment
Primary school completed
Assets

As defined above, relational capability (Relational Capability index) includes four main components which are: (i) living conditions/integration in networks, (ii) political commitment, (iii) private relations/friendship and love relationships, and (iv) solidarity. Appropriate indices are set up to describe each component on the basis of the answers to the corresponding questions in the questionnaire.

For 'the living conditions/ integration into networks', questions are related to the marital status, the education level, the professional training, 
skills acquisition, religion, social networking, feast attendance, infrastructures and communication means, media communication. For 'the political commitment/voluntary commitment within the community', questions deal with vote, participation in decision-making within the community, commitment within a group, ability to change one's life course and the effective means to do so.

To tackle the issue of 'private relations/friendship and love relationships', questions address the following issues: by whom one feels loved, what is the number of close friends, what assistance is needed, self-perception, the level of trust, children support, the perception of unity within the community.

Concerning solidarity, which addresses the issue of 'overabundance', the questions are related to the participation in community activities for the common good.

\section{Results}

The following tabular provides the weights attributed to the various components of each index considered.

\section{Poverty Exit index (PEI): weights}

\begin{tabular}{|l|l|l|l|}
\hline Dimension & Components & Weight: uniform (Yunus) & Weight: Alkire \& Santos \\
\hline Education & $\begin{array}{l}\text { Years of schooling } \\
\text { (primary completed) }\end{array}$ & $12.5 \%$ & $33.33 \%$ \\
\hline \multirow{3}{*}{ Health } & Healthcare & 12.5 & 11.11 \\
\cline { 2 - 4 } & Sanitary infrastructures & 12.5 & 11.11 \\
\cline { 2 - 4 } $\begin{array}{l}\text { Standard } \\
\text { of living }\end{array}$ & Eumber of meals per day & 12.5 & 11.11 \\
\cline { 2 - 4 } & Watertricity & 12.5 & 8.33 \\
\cline { 2 - 4 } & $\begin{array}{l}\text { Wall (not made } \\
\text { of mud/thatch) }\end{array}$ & 12.5 & 8.33 \\
\cline { 2 - 4 } & Assets & 12.5 & 8.33 \\
\hline
\end{tabular}

We are now ready to provide the findings obtained for each index. 
Poverty Exit index: results

\begin{tabular}{|l|l|l|l|}
\hline PEI & & Uniform & Alkire \& Santos \\
\hline Eastern Obolo & & 0.3436 & 0.4374 \\
\hline Onelga & Total core & 0.6318 & 0.673 \\
\cline { 2 - 4 } & Total non core & 0.6039 & 0.6561 \\
\cline { 2 - 4 } & Agip core & 0.6589 & 0.7004 \\
\cline { 2 - 4 } & Agip non core & 0.4832 & 0.5336 \\
\cline { 2 - 4 } & $\begin{array}{l}\text { Total (core } \\
\text { \& non core) }\end{array}$ & 0.60 & 0.66 \\
\cline { 2 - 4 } & $\begin{array}{l}\text { Agip (core } \\
\text { \& non core) }\end{array}$ & 0.54 & 0.59 \\
\cline { 2 - 4 } & Non Host & 0.6985 & 0.7468 \\
\hline
\end{tabular}

The Relational Capability index (RCI) is given by:

$$
\mathrm{RCI}=(1-\mathrm{PEI}) \times C 1+\mathrm{PEI} \times C 2 / 3+\mathrm{PEI} \times C 3 / 3+\mathrm{PEI} \times C 4 / 3,
$$

where PEI is itself calculated with the uniform weighting.

The closer is the population to the poverty exit level (the closer to 1 is the PEI), the higher is the weight put on the quality of the social networks, that is to say, on components 2, 3 and 4 of the RCI: political commitment, private relations, solidarity. On the contrary, the lower is the PEI (close to 0 ), the higher is the weight given to the access to material resources (component 1).

This PEI-dependent weighting may change across time and area. Such a "dynamic" weighting is one way to solve the classical methodological problem of the weighting choice in the construction of aggregated indices: this problem concerns all the current indices, as the GDP or the HDI. Our dynamic weighting also tries to answer the critics frequently addressed to the analysis in terms of social networks: such an analysis would show that the poor, without knowing it, are socially richer than the rich and could lead to the following conclusion: why bother with the conditions for a socially sustainable development? Moreover, in order to get an index that could be adapted to different socio-economic contexts, the dynamic weighting also takes into account the specificity of each area in terms of poverty exit. Finally, the adaptive character of our weighting helps refine the diachronic comparisons in a given area. At time $t+1$, material conditions may have improved compared to previous period $t$ but it does not provide any information about the evolution of RCI. The RCI score will increase if the 
improvement of EPI goes hand in hand with an improvement of $C_{1}$ or of the quality of the social networks (measured by components $C_{2}, C_{3}$ and $C_{4}$ ). Otherwise, RCI could stay even or even be reduced although the living conditions improved.

Relational Capability index

\begin{tabular}{|l|l|l|l|}
\hline RCI & & Uniform weight & Dynamic weight \\
\hline Eastern Obolo & & 0.7017 & 0.5535 \\
\hline Onelga & Total core & 0.6936 & 0.6266 \\
\cline { 2 - 4 } & Total non core & 0.7057 & 0.5887 \\
\cline { 2 - 4 } & Agip core & 0.6837 & 0.6220 \\
\cline { 2 - 4 } & Agip non core & 0.6473 & 0,5431 \\
\cline { 2 - 4 } & Total core \& non core & 0.69 & 0.68 \\
\cline { 2 - 4 } & Agip core \& non core & 0.66 & 0.64 \\
\cline { 2 - 4 } & Non Host & 0.7039 & 0.6569 \\
\hline
\end{tabular}

\begin{tabular}{|c|c|c|}
\hline \multirow{2}{*}{\multicolumn{3}{|c|}{$\begin{array}{l}\text { Component } 1 \\
\text { Living conditions }\end{array}$}} \\
\hline & & \\
\hline \multicolumn{2}{|c|}{ Eastern Obolo } & 0.5273 \\
\hline \multirow[t]{8}{*}{ Onelga } & Total core & 0.6944 \\
\hline & Total non core & 0.6466 \\
\hline & Agip core & 0.6774 \\
\hline & Agip non core & 0.5770 \\
\hline & Total core \& non core & 0.65 \\
\hline & Agip core \& non core & 0.63 \\
\hline & Non Host & 0.6528 \\
\hline & & 0.6599 \\
\hline
\end{tabular}

\begin{tabular}{|l|l|l|}
\hline $\begin{array}{l}\text { Component 2 } \\
\text { Political commitment }\end{array}$ \\
\hline Eastern Obolo & & 0.8329 \\
\hline Onelga & Total core & 0.7943 \\
& Total non core & 0.854 \\
& Agip core & 0.801 \\
& Agip non core & 0.7797 \\
& Total core \& non core & 0.78 \\
& Agip core \& non core & 0.73 \\
& Non Host & 0.8294 \\
\cline { 2 - 3 } & & 0.8001 \\
\hline
\end{tabular}




\begin{tabular}{|l|l|l|}
\hline $\begin{array}{l}\text { Component 3 } \\
\text { Private relations }\end{array}$ \\
\hline Eastern Obolo & & 0.5986 \\
\hline Onelga & Total core & 0.6321 \\
& Total non core & 0.6139 \\
& Agip core & 0.62 \\
& Agip non core & 0.6194 \\
& Total core \& non core & 0.61 \\
& Agip core \& non core & 0.6 \\
& Non Host & 0.6151 \\
\cline { 2 - 3 } & & 0.6235 \\
\hline
\end{tabular}

\begin{tabular}{|l|l|l|}
\hline \multicolumn{2}{|l|}{$\begin{array}{l}\text { Component } 4 \\
\text { Solidarity }\end{array}$} \\
\hline Eastern Obolo & & .8478 \\
\hline Onelga & Total core & 0.6536 \\
& Total non core & 0.7083 \\
& Agip core & 0.6363 \\
& Agip non core & 0.612 \\
& Total core \& non core & 0.6 \\
& Agip core \& non core & 0.64 \\
& Non Host & 0.7183 \\
\cline { 2 - 3 } & & 0.6472 \\
\hline
\end{tabular}

In terms of PEI, Onelga performs better than Eastern Obolo. But in terms of RCI, with a uniform weighting, Eastern Obolo does better than Onelga, even if component $\mathrm{C} 1$ favours Onelga. A uniform weighting gives an advantage to EO in terms of RCI compared to PEI. Nevertheless, a dynamic weighting (depending on PEI) stresses the importance of material poverty in Eastern Obolo and provides equal RCI-based scores to the two areas under scrutiny. The results, component by component, help to refine these observations.

The comparison between the two areas, in terms of material living conditions, shows the positive impacts of the oil companies' presence for their host communities: the core communities, as well as the non core communities located not far away, benefit from free access to electricity and drinking water. The poverty exit levels of Eastern Obolo represents the half of Onelga's PEI.

If Eastern Obolo is worse off than Onelga in terms of level of life, it performs better in terms of political commitment and solidarity. This confirms the observation regarding the social climate on the field, which was much 
better in the coastal area than in the oil producing areas. Are these results directly related to oil production? The two areas belong to two different ethnic groups (the Ogba in Onelga and the Andoni in Eastern Obolo). These two ethnic groups have different social and political traditions. This constitutes a limit to our comparison between the two areas. For this reason, it is important to refine the comparison between core and non core communities, in the homogenous Onelga Local government. The comparison between Total non core communities and Agip non core communities is also interesting: Agip non core communities have not benefitted from any $\mathrm{MoU}$ with Agip, whereas Total has signed one MoU with its core communities and one MoU with the whole Egi clan, which means that Total non core communities have had access to certain projects and services. Anyway, in terms of living conditions, it is clear that the governments in both areas have had a minimal commitment until recently. As a result, the material standards of living in the host communities depend largely on the programs led by oil companies to get their social licence to operate. On the contrary, the low levels in Eastern Obolo show the lack of governmental commitment, until 2008 and the weak impact of the local development foundation financed by Total. In terms of social networks, people value the integrity of local leaders in Eastern Obolo, their attention to the poor and their positive contribution to the social climate, much more than in Onelga. ${ }^{4}$ Of course, this can be easily explained by the nature of the relations between organizations and populations. The local development foundation in the coastal area is exclusively made up of people from neighbouring villages and has for sole aim the contribution to participatory development projects. As far as oil companies are concerned, the emphasis is put on the oil and gas production and its impacts as well as on the management of projects benefiting to the population. Local communities have been involved for a longer time in the relationship with the companies, and this has led to increased clientelist relations and mistrust from the stakeholders.

\footnotetext{
${ }^{4} 23.5 \%$ of the interviewees in Total host communities (Onelga), $14.5 \%$ in Agip (Onelga) and $53 \%$ in Eastern Obolo state that the leaders (from the Company and from the Foundation) are consistent in word and deed. As regards the leaders' loyalty towards the community, the scores amount respectively to $22.5 \%$ (Total host communities), $15.5 \%$ (Agip) and 65\% (Eastern Obolo). To the question "Has the Company [resp. Foundation] respected people, their culture and their environment ?", the answer is "yes" at $40 \%$ for Total, $25.5 \%$ for Agip, and $59.5 \%$ for the Eastern Obolo Foundation.
} 


\section{How to foster the relational capability ?}

In this section, we present our last results. They have been obtained by means of a double regression between various variables that can be handled with within appropriate policies and the relational capability. Our purpose is to identify which variables have a robust impact on the population's relational capability. We had to rely on a double regression methodology in order to get rid of the endogeneity issue between RCI and the variables under scrutiny.

Our main findings are the following: for Agip Core communities, microcredit and access to education seem to be the two key variables ; for Agip Non core communities, only microcredit seems to have a robust, positive influence on people's relational capability. For Eastern Obolo, again, microcredit emerges as the most influential variable while all the other variables (access to safe drinking water, transportation, education, healthcare) are also robustly beneficial in terms of relational capability. Roughly the same conclusion can be drawn for Onelga Non host communities and Total Non Core communities. For Total Core communities, on the other hand, microcredit emerges, once again, as the key variable, but access to education is also quite robust (though less influential). 
Total Core communities

\begin{tabular}{|c|c|c|c|c|c|}
\hline Variables & Coef. & Std. Err. & T-stat. & P-val. & Int. Conf. \\
\hline Acces to safe & 0.0171 & $(0.0192)$ & 0.888 & 0.376 & $-0.0209-0.055$ \\
drinking water & & & & & \\
Access to trans- & 0.00412 & $(0.0242)$ & 0.170 & 0.865 & $0.0436-0.0518$ \\
portation & & & & & \\
Access to education & $0.0706^{* * *}$ & $(0.0265)$ & 2.663 & 0.00837 & $0.0183-0.123$ \\
Access to healthcare & 0.00384 & $(0.0127)$ & 0.303 & 0.762 & $-0.0212-0.0288$ \\
Take a loan in the & $0.271^{* * *}$ & $(0.025)$ & 10.85 & 0 & $0.222-0.321$ \\
past 5 years & & & & & \\
\hline Observations & 210 & & & & \\
R-squared & 0.942 & & & & \\
\hline \multicolumn{7}{|c|}{ Robust standard errors in parentheses } \\
\\
${ }^{* * *} p<0.01,{ }^{* *} p<0.05,{ }^{*} p<0.1$ \\
\hline
\end{tabular}

Total Non Core communities

\begin{tabular}{|c|c|c|c|c|c|}
\hline Variables & Coef. & Std. Err. & T-stat. & P-val. & Int. Conf. \\
\hline Acces to safe & -0.0422 & $(0.0342)$ & -1.233 & 0.224 & $-0.111-0.0268$ \\
drinking water & & & & & \\
Access to trans- & 0.0511 & $(0.0310)$ & 1.65 & 0.106 & $-0.0114-0.114$ \\
portation & & & & & \\
Access to education & 0.0231 & $(0.0429)$ & 0.539 & 0.593 & $0.0635-0.11$ \\
$\begin{array}{c}\text { Access to healthcare } \\
\text { Take a loan in the } \\
\text { past 5 years }\end{array}$ & $0.0288^{* *}$ & $(0.0123)$ & 2.340 & 0.0241 & $0.00397-0.0537$ \\
& & $(0.0418)$ & 7.04 & $1.27 \mathrm{e}-08$ & $0.21-0.379$ \\
\hline $\begin{array}{c}\text { Observations } \\
\text { R-squared }\end{array}$ & 47 & & & & \\
\hline \multicolumn{7}{|c|}{ Robust standard errors in parentheses } \\
\hline
\end{tabular}


Agip Core communities

\begin{tabular}{|c|c|c|c|c|c|}
\hline Variables & Coef. & Std. Err. & T-stat. & P-val. & Int. Conf. \\
\hline Acces to safe & -0.0096 & $(0.0194)$ & -0.494 & 0.622 & $-0.0479-0.0287$ \\
drinking water & & & & & \\
Access to transportation & 0.0352 & $(0.0257)$ & 1.368 & 0.173 & $-0.0156-0.0860$ \\
Access to education & 0.00971 & $(0.0273)$ & 0.356 & 0.723 & $-0.0442-0.0636$ \\
Access to healthcare & 0.0143 & $(0.015)$ & 0.953 & 0.342 & $-0.0153-0.0439$ \\
Take a loan in the & $0.301^{* * *}$ & $(0.0270)$ & 11.15 & 0 & $0.248-0.355$ \\
past 5 years & & & & & \\
\hline Observations & 182 & & & & \\
R-squared & 0.951 & & & & \\
\hline
\end{tabular}

Robust standard errors in parentheses

$$
{ }^{* * *} p<0.01,{ }^{* *} p<0.05,{ }^{*} p<0.1
$$

\section{Agip Non Core communities}

\begin{tabular}{|c|c|c|c|c|c|}
\hline Variables & Coef. & Std. Err. & T-stat. & P-val. & Int. Conf. \\
\hline Acces to safe & 0.0193 & $(0.0209)$ & 0.922 & 0.358 & $-0.0221-0.0607$ \\
drinking water & & & & & \\
Access to transportation & 0.0177 & $(0.0216)$ & 0.821 & 0.414 & $-0.0250-0.0604$ \\
Access to education & 0.0108 & $(0.0312)$ & 0.346 & 0.730 & $-0.0509-0.0725$ \\
Access to healthcare & 0.0229 & $(0.0204)$ & 1.122 & 0.264 & $-0.0175-0.0633$ \\
Take a loan in the & $0.249^{* * *}$ & $(0.0297)$ & 8.384 & 0 & $0.190-0.308$ \\
past 5 years & & & & & \\
\hline Observations & 120 & & & & \\
R-squared & 0.937 & & & & \\
\hline
\end{tabular}

Robust standard errors in parentheses

$$
{ }^{* * *} p<0.01,{ }^{* *} p<0.05,{ }^{*} p<0.1
$$


Eastern Obolo communities

\begin{tabular}{|c|c|c|c|c|c|}
\hline Variables & Coef. & Std. Err. & T-stat. & P-val. & Int. Conf. \\
\hline $\begin{array}{c}\text { Acces to safe } \\
\text { drinking water }\end{array}$ & $0.0956^{* * *}$ & $(0.00509)$ & 18.77 & 0 & $0.0856-0.106$ \\
Access to trans- & $0.0109^{*}$ & $(0.00589)$ & 1.848 & 0.0650 & $-0.0006-0.0224$ \\
portation & & & & & \\
Access to education & $0.0304^{* * *}$ & $(0.00575)$ & 5.297 & $1.57 \mathrm{e}-07$ & $0.0192-0.0417$ \\
Access to healthcare & $0.0350^{* * *}$ & $(0.00574)$ & 6.105 & $1.69 \mathrm{e}-09$ & $0.0238-0.0463$ \\
Take a loan in the & $0.152^{* * *}$ & $(0.00713)$ & 21.36 & 0 & $0.138-0.166$ \\
past 5 years & & & & & \\
\hline Observations & 718 & & & & \\
R-squared & 0.983 & & & & \\
\hline \multicolumn{7}{|c|}{ Robust standard errors in parentheses } \\
\hline \multicolumn{7}{|c|}{$p<0.01,{ }^{* *} p<0.05,{ }^{*} p<0.1$} \\
\hline
\end{tabular}

\section{Conclusion}

The strategies implemented by the private sector in order to fight poverty at the Bottom of the Pyramid (Prahalad, 2005) are not only related to the consumption goods industries, that adapt their products and their cost structures to the deprived populations. Extractive industries, in particular oil companies, can act at a double level: they can provide access to cheap energy to the poor. Several groups have recently financed a study done by Hystra and Ashoka (an organization which provides support to social businesses all over the world) (Aron al., 2009): the aim is to promote new energy-relative behaviours from the producers, suppliers and customers, in different countries. It is the expression of new collaborations between private actors and social entrepreneurs. This could help to implement new programs in the oil producing areas, in Nigeria, where local communities depend on free electricity provided by the companies' turbines, which is not sustainable on a long-term basis (what about the future, when the companies have left the place?)

Moreover, these projects are marginal in comparison with the challenges related to oil production and its impacts on the populations of producing countries. This is why the second challenge for oil companies consists in a mental revolution regarding their role in the producing areas. This article shows that there have been slight changes these past years. We can mention the efforts in terms of fiscal transparency (the majors as well as the Nigerian government have signed the EITI - Extractive Industry Trans- 
parency Initiative) and the recognition of the role to play in order to promote socio-economic development at a local and regional levels: new partnerships express the will to cooperate with other actors, knowing that nobody has a ready-made solution. The conditions for success are: 1) getting gradually rid of old clientelist and nepotist practices (from this perspective, the presence of third parties, acting as mediators, appear to be crucial); 2) involving the poorest people and groups, focusing on programs that tend to reduce inequalities and violence; 3) minimizing the direct and indirect impacts of oil production, particularly gas flaring and looking precisely at the socio-economic commitment of the corporation in terms of empowerment of the local populations: for the time being, companies only publish their best practices. The publication of figures and key societal performance indices would help. This is where the two indices presented here could be useful: The outcomes and impacts of projects do matter as much as the financial resources spent by the companies for these projects. Our survey indicates the challenges both for the middle management in charge of the daily relationships with stakeholders and for the top management that has to commit into a new governance model, involving conventional and new actors, in an innovative, yet uncertain but promising way.

We believe, however, that the scope of our indices is not restricted to multinationals operating in Southern countries. In the spirit of the work already done by OPHI and the UNDP, we understand both PEI and RCI as promising tools for a better understanding of the way various local actors not just corporations - can foster human development in emerging countries. These very indices could as well provide precious informations about the quality of social networks in Northern countries. Such developments are left for further research.

\section{References}

[1] Alkire, S. M-E Santos, "Acute Multidimensional Poverty : a new Index for Developing Countries", United Nations Development Programme, Human Development Reports, Research Paper 2010/11, July 2010, http://hdr.undp.org/en/reports/global/hdr2010/papers/HDRP ${ }_{2} 010_{1} 1$.pdf.

[2] Aron J-E, O. Kayser, L. Liautaud, A. Nowlan, "Access to Energy for the Base of the Pyramid", Oct. 2009, www.hystra.com.

[3] Bach D., "Nigeria : paradoxes de l'abondance et démocratisation en trompe-l'œil", Afrique contemporaine, n. 219, p. 119-135, 2006/3. 
[4] Blowfield M. \& J.G. Frynas, "Setting new agendas: critical perspectives on Corporate Social Responsibility in the developing world", International Affairs, n. 81/3, p.499-513, 2005.

[5] Bollecker M. et P. Mathieu, "Vers des systèmes de mesure des performances sociétales. L'apport des conventions", Revue française de gestion, n. 180, p.89-102, 2008/1.

[6] Boltanski L.et E. Chiapello, Le Nouvel Esprit du Capitalisme, Gallimard, Paris, 1999.

[7] Bomann-Larsen L. \& O. Wiggen (dir.), Responsibility in World Business. Managing harmful effects of corporate activity, UN University Press, New York, 2004.

[8] Fanchette F., "Le Delta du Niger: rivalités de pouvoir, revendications territoriales et exploitation pétrolière ou les ferments de la violence", Hérodote, n.121, p.190-220, 2d. trim. 2006.

[9] Frynas J.G., "The false developmental promise of CSR: evidence from multinational oil companies", International Affairs 81 (3), p.581-598, 2005 .

[10] — "Corporate social responsibility and international development: critical assessment", Corporate Governance, vol. 16 n. 4, p.274$281,2008$.

[11] - Beyond Corporate Social Responsibility, Cambridge University Press, Cambridge, 2009.

[12] Gabriel P. et P. Gabriel, "Diffusion du développement durable dans le monde des affaires. Un schéma conventionnel", Revue française de gestion, n.152, p.199-213, 2004/5.

[13] Gille L., Aux Sources de la valeur. Des biens et des liens, L'Harmattan, Paris, 2006.

[14] Giraud G. \& C. Renouard, "Relational Capability: an index of collective empowerment", ESSEC Working paper, DR09012, dec 2009.

[15] Guichaoua Y., "Oil and political violence in Nigeria", Governance of oil in Africa: unfinished business, Ifri, Paris, 2009.

[16] Hamilton J., L. Stockman, M. Brown, G. Marshall, G. Muttitt, \& N. Rau, The case for an oil-free future, www.nonewoil.org, 2004. 
[17] Idemudia U., "Oil extraction and poverty reduction in the Niger Delta: a critical examination of partnership initiatives", Journal of Business Ethics, n.90, p.91-116, 2009.

[18] Moreau-Defarges P., "Le pétrole? Un produit finalement comme les autres", Etudes, Paris. p.453-463, 2006.

[19] Nwajiaku K., "Between discourse and reality. The Politics of Oil and Ijaw Ethnic Nationalism in the Niger Delta", Cahiers d'Etudes africaines, XLV (2), n.178, p.457-459, 2005.

[20] Oyefusi A., "Oil and the Propensity to Armed Struggle in the Niger Delta Region of Nigeria", World Bank Policy Research Working Paper 4194, April 2007.

[21] Prahalad, C.K., The Fortune at the Bottom of the Pyramid. Eradicating Poverty through Profits, Upper Saddle River, NJ: Wharton School Publishing, 2005.

[22] Pratten D., "The Politics of Vigilance in South-eastern Nigeria", Development and Change, vol. 37, No. 4, 2006.

[23] Renouard C., La Responsabilité éthique des multinationales, PUF, Paris, 2007.

[24] — Un monde possible, Paris, Seuil, 2008.

[25] — "CSR, Utilitarianism and the Capabilities Approach", Journal of Business Ethics, vol 98 (1), p.85-97, 2010.

[26] Ricœur P., Soi-même comme un autre, Seuil, Paris. Transl. 1992. Oneself as Another, University of Chicago Press, Chicago, 1990.

[27] Sébille-Lopez P., "Les hydrocarbures au Nigeria et la redistribution de la rente pétrolière", Afrique contemporaine, p.157-181, 2005.

[28] Sen A., Development as Freedom, Knopf, New York, 1999.

[29] - Spheres of Justice, Blackwell, Oxford, 1983.

[30] Watts M., "Development and Governmentality", Singapore Journal of Tropical Geography, 24(1), p.6-34, 2003. 
ESSEC Business School Avenue Bernard Hirsch BP 50105

95021 Cergy-Pontoise Cedex France

Tél. + $33(0) 134433000$

Fax $+33(0) 134433001$

www.essec.fr

ESSEC Executive Education

CNIT BP 230

92053 Paris-La Défense

France

Tél. +33(0)146924900

Fax +33(0)1 46924990

http:l/formation.essec.fr

ESSEC Business School

Singapore Campus

100 Victoria Street

National Library Building \# 13-02

Singapore 188064

essecasia@essec.fr

Tél. +65 68849780

Fax +6568849781

www.essec.edu

\section{Informations}

Hanane Rahmoune +33 (0)134433358

rahmoune@essec.edu

www.essec.fr

research.center@essec.fr

ISSN 1291-9616 